$\left(\begin{array}{ccc}\text { Jpn. J. Hosp. } & \text { Pharm. } \\ \text { 資 } & \text { 料 } \\ 22(6) & 615-627 & (1996)\end{array}\right)$

注射薬処方オーダリングシステムを利用した注射薬個人別セット化の試み

[I ] 注射薬処方オーダリングシステムの運用と評価 $\dagger^{1}$

古川裕之 $\dagger^{2}$, 毎田千恵子 $\dagger^{2}$, 大森美加子 $\dagger^{2}$, 中島恵美 $\dagger^{2}$, 市村藤雄 $\dagger^{2}$, 佐藤 保 $\dagger^{3}$, 分校久志 $\dagger^{3}$, 高前田哲夫 $\dagger^{3}$, 猪島哲也 $\dagger^{3}$, 宮崎逸夫 $\dagger^{4}$, 中野 修 $\dagger^{5}$, 斉藤晴彦 $\dagger^{6}$

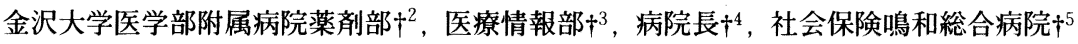

NEC 北陸ソフトウェア株式会社 $\dagger^{6}$

\title{
Supply of Injectable Drugs for Individual Patients Using the Prescription Entry System
}

\section{[1] Evaluation of the Prescription Entry System of Injectable Drugs $\dagger^{1}$}

HIROYUKI FURUKAWA $\dagger^{2}$, CHIEKO MAIDA $\dagger^{2}$, MIKAKO OMORI $\dagger^{2}$, EMI NAKASHIMA $\dagger^{2}$, FUJIO ICHIMURA $\dagger^{2}$, TAMOTSU SATO $\dagger^{3}$, HISASHI BUNKO ${ }^{3}$, TETSUO TAKAMAEDA $\dagger^{3}$, TETSUYA INOSHIMA $\dagger^{3}$, ITSUO MIYAZAKI $\dagger^{4}$, OSAMU NAKANO $\dagger^{5}$ and HARUHIKO SAITO $\dagger^{6}$, Kanazawa University Hospital Pharmacy $\dagger^{2}$, Department of Medical Informatics $\dagger^{3}$, Director of Hospital $\dagger^{4}$, Naruwa Hospital $\dagger^{5}$, NEC Corporation $\dagger^{6}$

$$
\left(\begin{array}{l}
\text { Received June 11, } 1996 \\
\text { Accepted September 19, } 1996
\end{array}\right)
$$

The prescription entry system for injectable drugs which runs on the ACOS system 3600 /6 (ORDERIG : NEC Corporation) was newly implemented on Apr.3, 1995 for both inpatients and outpatients of Kanazawa University Hospital. The system has been accepted by both physicians and nurses. A $100 \%$ entried prescription rate via the system was achieved within one week after the implementation and this system has continued to run smoothly without any problems up to, now.

The implementation of thus system made the supply of injectable drugs for individual patients possible, but the system still needs to develop a check fuction for prescriptions (especialy regarding imcompatibility).

Key words - prescription entry system, injectable drugs, pharmacoinformatics, pharmaceutical service, dispensing

$$
\text { はじめに }
$$

注射薬処方オーダリングシステム（以下，注射 オーダリングシステム) の導入は, 処方オーダリ ングシステムに比べて困難であるとされている.
その主な理由として, (1)注射薬には診療報酬請求 上の制約が多いこと，(2)処方入力者である医師の 同意と協力が得にくいこと, さらに(3)処方後の注 射薬供給システムの整備が困難であることがあげ られる。 
医師の同意と協力が得にくい原因として, 注射 薬による治療の特殊性（1)注射薬を用いる治療は 緊急性が高いこと, (2)注射薬を投与される患者の 多くは容態が不安定で, 処方変更の頻度が高いこ と，(3)投与指示が細かいこと）による注射薬処方 入力の煩雑さがあげられる. 一方, 処方入力され た注射薬の供給システムの整備（人員,搬送手段, 調剤スペース）もオーダリングシステム導入時の 大きな課題である。この結果, 大学病院のような 大規模施設における全面的な稼働は, 非常に困難 となっている。

金沢大学医学部附属病院では, 導入時の障害と なる問題点の解決に取り組み, 1995年 4 月 3 日よ り入院患者および外来患者の注射薬処方に対して オーダリングシステムを全面的に導入した。 今 回, 本院のシステムの概要と運用条件を紹介し, 1 年間の稼働経験と院内各スタッフ（医師, 看護 婦, 医事職員) 対象に行ったアンケート調査結果 をもとにして, 注射薬オーダリングシステムにつ いての分析と考察を試みたので報告する.

\section{1. システムの概要}

\section{1-1. 機器構成}

ホストコンピュータは ACOS3600/6NEC (32 MB) 2 台, ワークステーションは S3100/X 5 (32 ビット，2 MB）と N5200/03LS（16ビット， 2 MB）である。注射せん印字用としてラインプリ ンター（KLP-100C） 2 台, 病棟毎集計表印字用 としてカラーシリアルプリンター 1 台を薬剤部に 配置した。注射薬の処方入力は, 院内の各端末か

$\dagger^{1}$ 本報は, 第16回医療情報学連合大会（名古屋, 1995年11月）と平成 8 年度国立大学附属病院医 療情報システムシンポジゥム（東京, 1996年 1月）で発表.

$\dagger^{2,4}$ 金沢市宝町13-1;13-1,Takaramachi，Kanazawashi, 920 Japan

$\dagger^{5}$ 金沢市大樋町3-1; 3-1, Ohimachi，Kanazawashi, 920 Japan

$\dagger^{6}$ 東京都港区芝 5丁目 7-1；7-1, Shiba- 5 chome, Minato-ku, Tokyo, 108-01 Japan
ら可能である.

$1-2$.ソフトウェア

ソフトゥェアは NEC 標準パッケージ (3.0 版）を採用し，本院用にカスタムマイズした。基 本的には新しい機能を盛り込まずに標準パッケー ジを全面的に稼働させることにより，現行のパッ ケージシステムを分析した。

医師による入力を容易にするために，画面イメ ージとコマンド入力方法（PF キー入力）をすで に稼働している処方オーダリングシステムと同様 にした。また，メンテナンス（薬珮登録・削除） を容易にするために，処方オーダリングシステム と同一の薬㘊基本テーブルを採用した.

$1-3$. 稼働時間

ファイル整理（月 3 回午後 7 時停止）とシステ 么保守（月 1 回全日）による稼働時間短縮日およ び日次処理（毎日午前 4 時〜 5 時）によるシステ 厶停止時間帯を除いて，基本的には全日稼働を行 っている.

$1-4$. 注射薬オーダの対象

オーダ入力の対象は，外来患者および入院患者 の注射薬すべて（治験用注射薬を含む）である. ただし, 注射用麻薬と中央診療部門 (手術部, 放 射線部, 血液浄化部) で使用される注射薬（造影 剤, 手術中使用のもの）はオーダ対象外とし，そ れぞれ専用の指示せんを用いることにした。

入力された注射薬処方情報は日次処理により自 動的に 1 日単位に分解され，翌日分（週末と祝日 の場合は休日明け分）までが注射せん出力の対象 となる。

\section{2. 運用の概要}

2-1.オーダの手順

医師によるオーダは, 対象患者の処方入力画面 オープン後, (1)薬片名, (2)投与量, (3)注射手技 (=投与方法)，(4)手技コメント，(5)投与回数, (6)投与日数の順に入力操作が進行する.

薬剤名は頭 2 文字以上の入力で該当薬郕名が検 索され, HELP 領域（画面右半分）に表示され る. HELP 領域に表示された薬凨の中から必要な 
薬剤の番号を選択する。続いて，投与量をアンプ ル，バイアル，バッグあるいはボトル単位で入力 する. 投与量の入力は, 成分量の他, 小数点以下 2 桁まで可能である（図1）。
注射手技の入力は, 薬剤と投与量入力後に展開 する HELP 領域の注射手技の中から番号選択に より行う (図 2 )。検查・処置用注射薬の場合 は, 治療用の場合とは異なり注射手技料を保険請

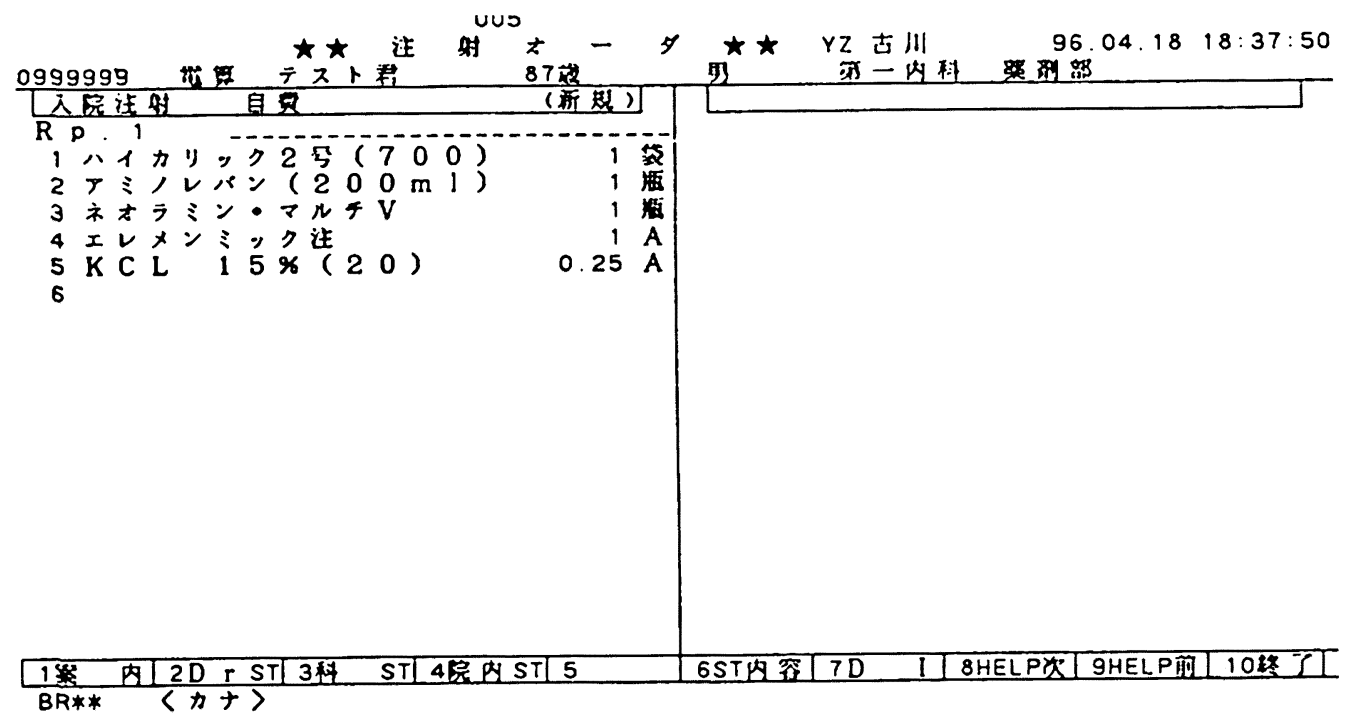

四 1．画面例（薬剤名と用量の入力例）

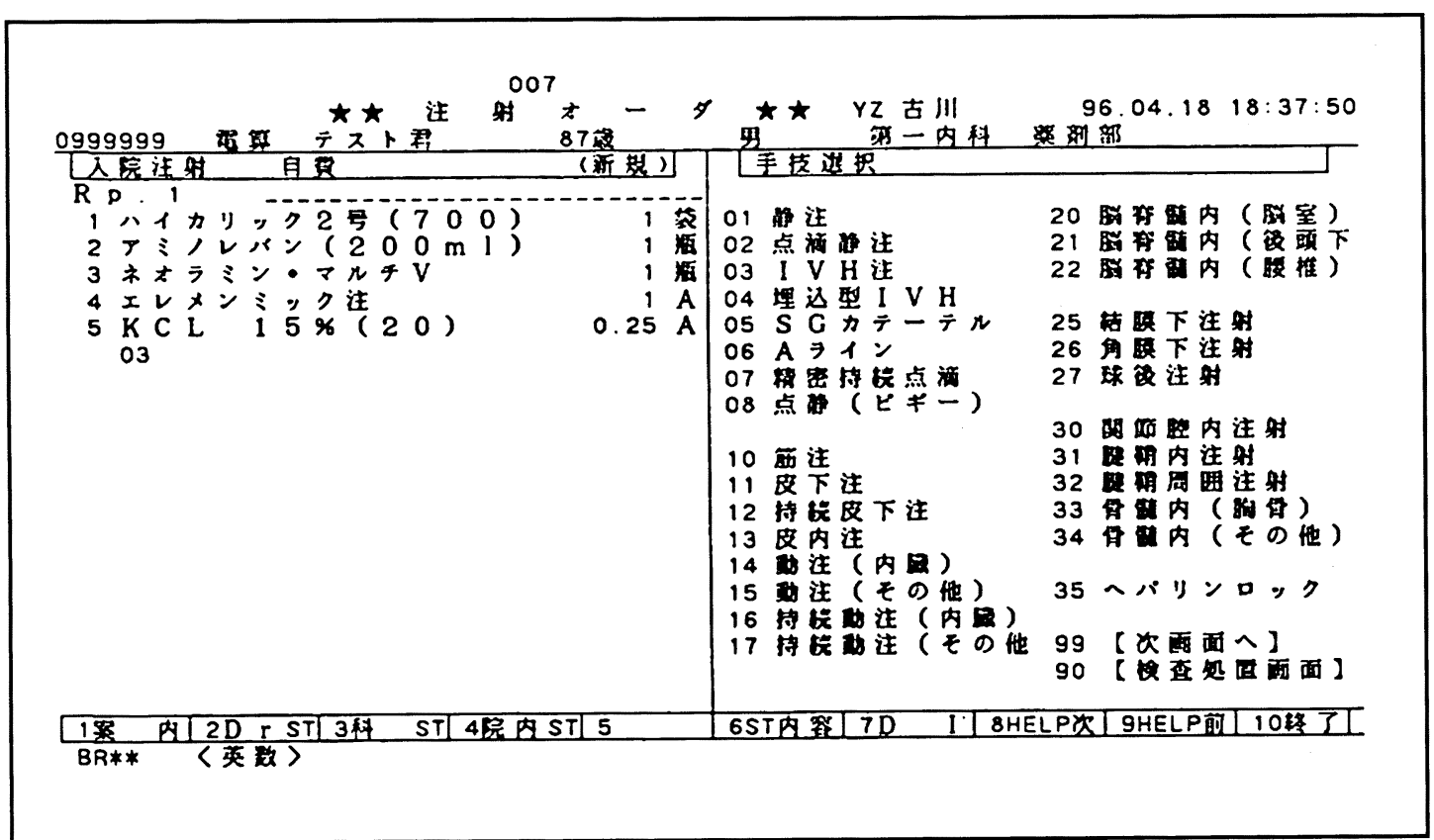

欧2。画面例（注射手技入力例） 


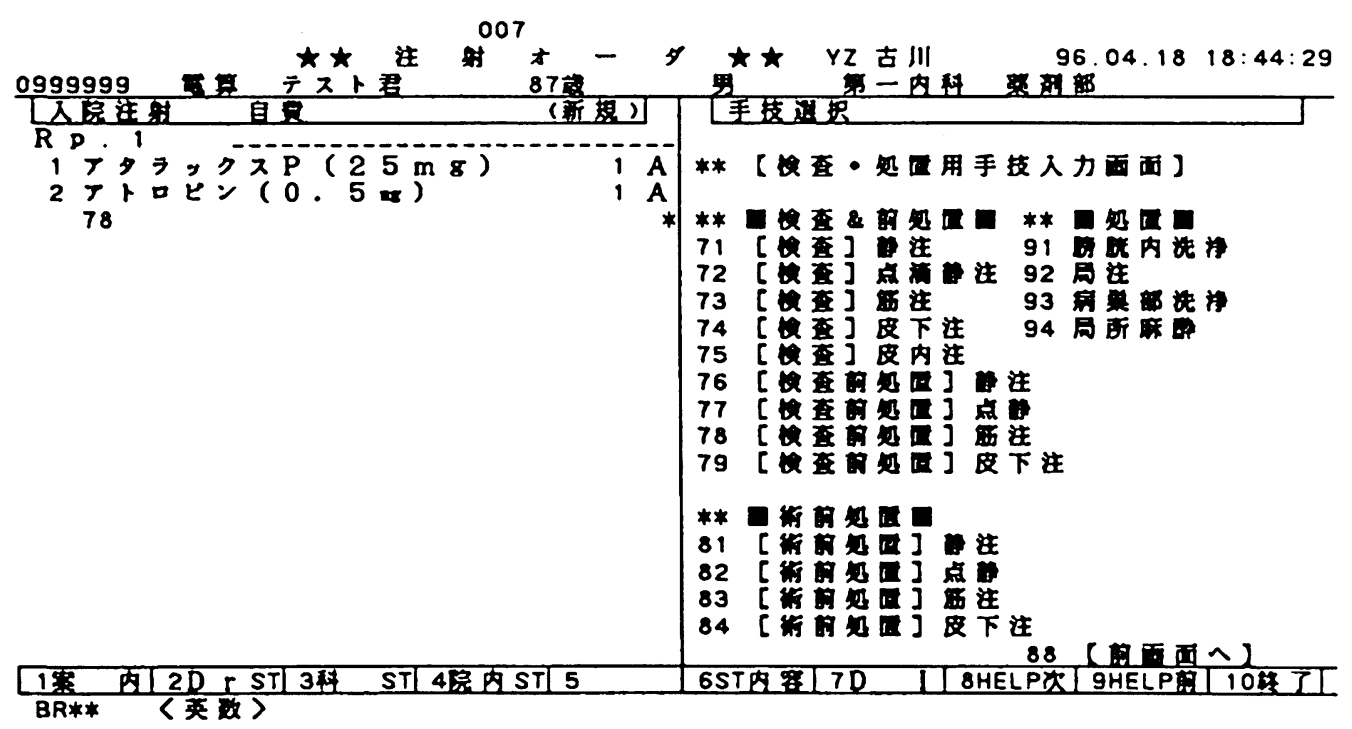

図 3 ，画面例（調査・処置用注射于技入力例）

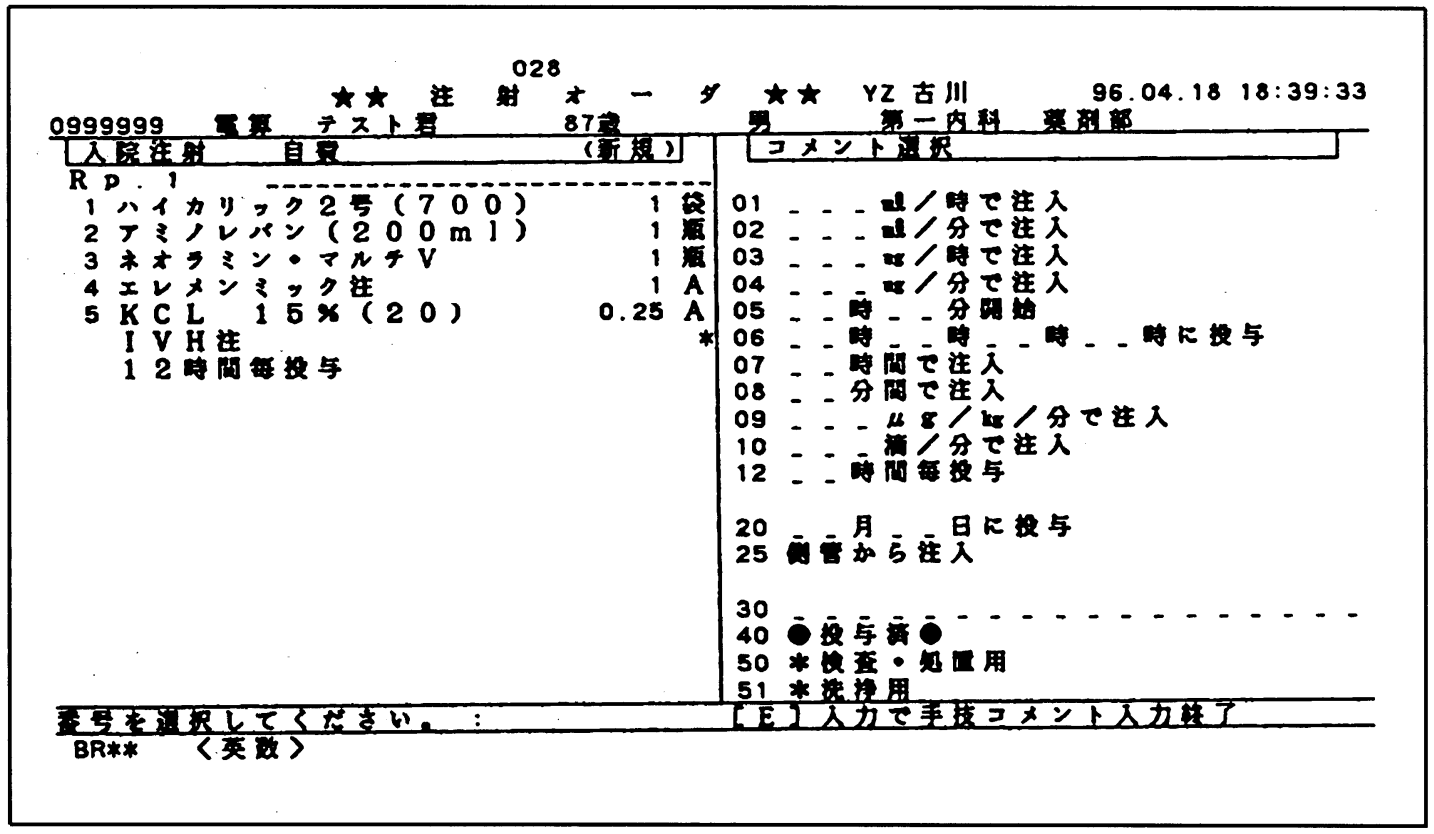

図 4．画面例（手技コメント人挒）

求できないので，専用の注射手技選択画面を設け た（図 3 )。注射手技の選択が終わると, HELP 画面は注射手技コメントを表示（図4）し，必要 に応じて 3 種類までの手技コメントを選択でき
る. 薬剤毎のコメント入力も 3 種類まで可能であ る。（図 5 ）。注射手技，薬骫コメントおよび手 技コメント入力後, 引き続いて回数人力と日数 （期間）入力を行う。以上のプロセスで，1 処方 


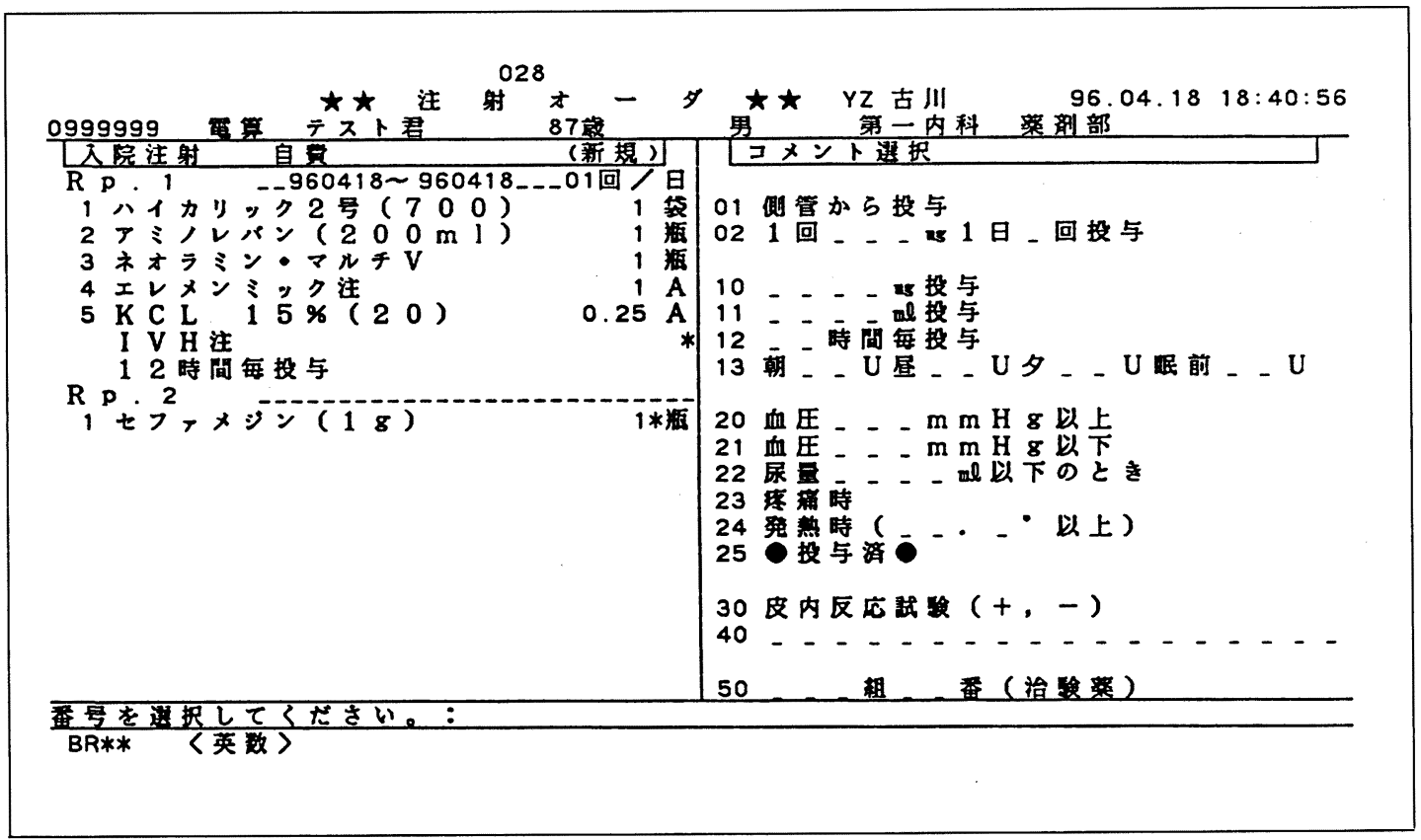

図 5.画面例（薬剤コメント入力例）

せんの入力が終了する. 処方せんが複数の場合 は，同じプロセスを繰り返す。

2-2.オーダ入力受付時間

オーダ対象注射薬については, 入院・外来を問 わず, システム稼働時間内はすべてオーダ入力と している.コンピュータ停止時間帯は専用の手書 き注射せんを用いている。

\section{$2-3$ ．注射せんの様式}

薬骫部のプリンターから印字される注射せんは 3 枚複写（薬棛部用, 病棟用, 医事連絡用) で, 処方内容を37行分を印字できる。また，注射せん の下部分に処方せん記載分の全注射薬について薬 剤毎集計を14行分印字 (50音順) するスペースを 確保し, 注射せん右側部分には患者氏名ラベルが 9 枚分印字できるよう設計した（図6）.

\section{2-4. 注射薬の供給方法}

オーダ入力された注射薬処方に対して，入院患 者の分については24時間を通して患者個人別セッ 卜を行っている．外来患者の分については定数配 置制を併用し，注射せん上の配置薬以外の注射薬 のみを患者単位に供給している。
入院患者では注射薬カートを用い, 注射せん一 括出力時に印字される「病棟毎注射薬集計表（以 下，病棟別集計表）」を利用して必要な注射薬を 全部準備した後, 注射せんに基づいて患者個人別 にセットを行っている．注射せんとセット済注射 薬の院内の流れを（図 7 ）に示す.

週末の複数日個人別セットをスムーズに行うた めに，注射せんと病棟別集計表の印字様式に次の 2 点の改良を加えた。

(1)注射せん：セット対象日分（複数日）について 患者毎に連続日で印字する。

(2)病棟別集計表：セット対象日分（複数日）の全 処方注射薬について薬剤毎に合計して50音順に印 字する(図 8 ).

2-5. 医事システムへの取り込み

医事システムには，ホストコンピュータ日次処 理（午前 4 時〜 5 時30分）により, 前日日付分の オーダ情報がすべて自動的に取り込まれる，処方 変更があれば，医師は日次処理時間までに画面修 正を行う。

投与中止分については，注射せん控（医事課連 


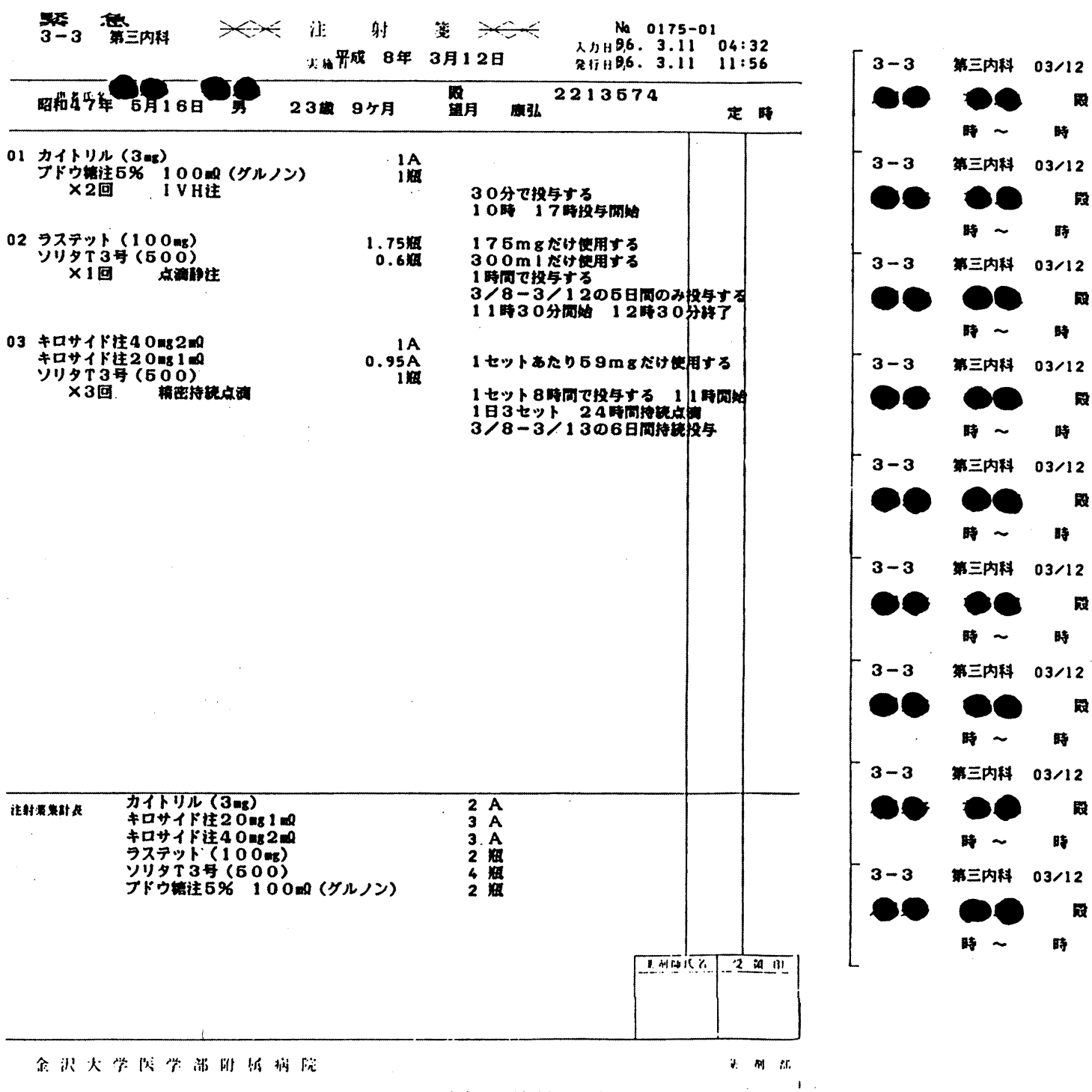

図6．注射せん例

絡用）を赤字で修正し，不要となった注射薬を添 えて翌日に薬片部へ提出する。薬骫部で返品注射 薬を確認後, 注射せん控（医事課伝達用）を医事 課へ送る。医事課では，医師の修正が行われてい ない場合に，修正された注射せんに基づいて画面 修正を行う。

\section{$2-6$. 運用の手引}

注射オーダリングシステムの利用を少しでも促 進するために，『操作マニュアル』とは別に『シ ステム運用の手引き』（A 4 サイズ：5頁）を作
成し各端末設置場所に配布した（図９）。この 『システム運用の手引き』の特徴は, 注射オーダ リングシステムを利用する上で直面する可能性が 高い疑問点を，Q＆A方式で25項目についてまと めている点にある，本操作マニュアルは毎年改訂 し 4 月に院内各部署に配布している。また，質問 が特に多い事項については，さらに詳細な説明の 必要性を判定し，付録として専用の入力マニュア ルを作成している．現在作成しているものとし て，(1)修正方法，(2)インスリン製剤の入力方法， 


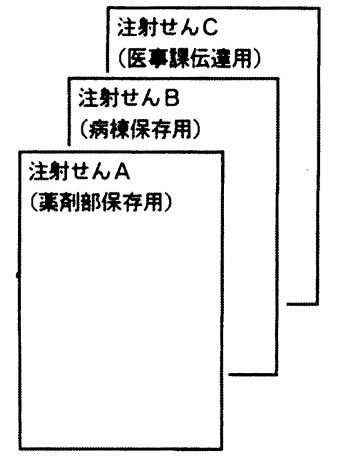

薬剤部

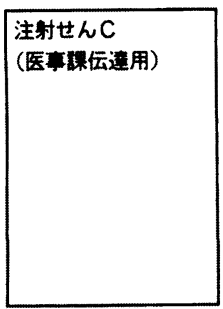

医事課

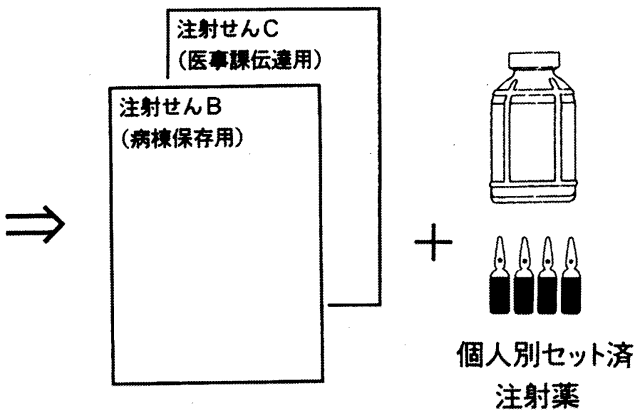

病 棟
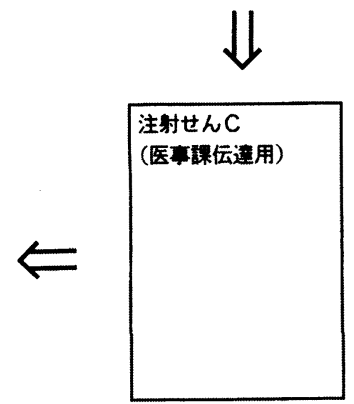

返品注射薬

\section{薬剤部}

図 7 . 注射薬処方せんの流れ

および(3検査・処置薬の入力方法マニュアルがあ る.

\section{3. システム稼働の状況}

3-1. システムの利用率 (オーダ率)

オーダ率は, システムの稼働開始後 1 週間以内 に100\%に達した, システム稼働後 1 年間 (1995 年 4 月～1996年 3 月）の追跡結果においても，才 一ダ率に変化は認められなかった。また医師の交 代期（10月，1月，4月）におけるオーダ率も変 化は認められず，システム操作方法と運用に関す る質問は $0 \sim 1$ 件/日程度であった。質問内容の 主なものは，(1)患者退院時の実施入力方法と(2)修 正方法であった。

\section{3-2. システム上のトラブル}

稼働 1 年間（1995年 4 月～1996年 3 月）のシス テム上の大きなトラブル発生は, 3 回であった. 原因別に, 日次处理（データ分解）上のトラブル によるものが 6 月 23 日と 6 月 25 日, データ分解用
カレンダー設定（人為的ミスによるも）が10月 2 日に発生した。 これら 3 件すべて, データ再分解 処理を行うことにより回復した。

また, 大きなトラブル以外に, 注射せんの一括 出力が病棟により実行できないトラブルが発生し ている. システム稼働 $1 \sim 2$ 力月間は $1 \sim 2$ 件/ 週の頻度で発生したが, 徐々に減少し過去 4 力月 （1996年 1 月〜 4 月）では $0 \sim 1$ 件/月の発生頻 度になっている，その原因は，注射手技コメント の入力トラブルの可能性が高いと分析している. このトラブルに対しては, 医療情報部で入力デー タを修正することで回復している．その所要時間 （月～木）は，入力処方データ量により異なり約 15 30分（金：約30分〜 1 時間）である.

4. 医師・看護婦・医事職員対象アンケート調査 結果

システムの稼働開始後 1 週間で, オーダ率は 100\%に達した。注射オーダリングシステムは， 
入院払出集計表 病棟：1-2 19:38 1 頁 実施時間：96年 3 月19日～96年 3 月19日 発行日：96年 3 月 18 日

\begin{tabular}{|c|c|c|}
\hline 薬 品 名 & 数 & 払出印 \\
\hline \multicolumn{3}{|l|}{ [普通薬］ } \\
\hline 001 アデラビン 9 号 & $12 \mathrm{~A}$ & \\
\hline 002 アドナ $(100 \mathrm{mg})$ & $1 \mathrm{~A}$ & \\
\hline 003 アドナ $(25 \mathrm{mg})$ & $1 \mathrm{~A}$ & \\
\hline $004 \quad$ アリナミン (10mg) & $5 \mathrm{~A}$ & \\
\hline 005 エフオーワイ (100mg) & 4 瓶 & \\
\hline 006 エフォーワイ (500mg) & 3 瓶 & \\
\hline 007 エレメンミック注 & $2 \mathrm{~A}$ & \\
\hline
\end{tabular}

\begin{tabular}{l|l}
\hline [冷所 (普通薬)] & \\
\hline $043 \quad$ グラン注 $(75 \mu \mathrm{g})$ & $1 \mathrm{~A}$ \\
\hline $044 \quad$ グルカゴン注 $1 \mathrm{U} \mathrm{S} \mathrm{P}$ 単位 & 1 瓶 \\
\hline $045 \quad$ セフォペラジン $(1 \mathrm{~g})$ & 2 瓶 \\
\hline 【継続有り】 & \\
\hline
\end{tabular}

\begin{tabular}{|c|c|c|}
\hline [点滴 & (普通薬)］ & \\
\hline 050 & アクチット（500） & 1 瓶 \\
\hline 051 & アミゼット10X（200） & 6 瓶 \\
\hline 052 & アミノトリパ1号（850） & 2 組 \\
\hline 053 & アミノトリパ1号（900） & 4 組 \\
\hline 054 & アミノレバン (200ml) & 5 瓶 \\
\hline 055 & アミパレン (200) & 8 瓶 \\
\hline 056 & 10\%イントラリボス（250） & 1 瓶 \\
\hline
\end{tabular}

図 8，病棟毎集計表例

医師，看護婦，薬剤師さらに医事職員など立場の 異なる広範囲の職種にまたがるシステムである. したがって, 導入した注射オーダリングシステム に対する各職種の受け止め方を調査するために， アンケート調查を実施した。医師と看護婦への調 查は, 稼働後 3 力月を経た 7 月に実施した（対 象：医師・看護婦各 100 人)。また，医事職員への 調查は, 稼働後 6 力月を経た 10 月に実施した（対 象：外来担当 13 人，入院担当 10 人）. 調查項目
は，一部の共通項目を除き，各職種のシステムの 関わり方を考慮したものとした。

\section{4-1. 医師の評価}

医師に対しては，特に操作方法への評価に重点 を置いた，回答率は77\%（100人中77名）であっ た. 設問「システムの操作に慣れたか？」に対し ては，75\%が「はい」，21\%が「いいえ」と答え た。また，設問「処方時にはどちらが便利か？」 に対しては，「手書き」が40\%，「コンピュータ入 


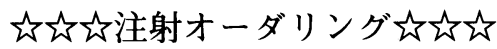
システム運用の手引き（96年版）
1996年 4 月25日

医療情報部・薬剤部

「注射処方オーダリング・システム」について, 疑問に思われる点を Q \& A 方式でまとめ てみました。正確には, 注射薬を含めて「処方オーダリング・システム」と表現する方が 良いのですが，すでに稼働している「処方オーダリング・システム」とは独立したシステ ムなので, ここでは「注射オーダリング・システム」と表現して区別します。

\section{Q 1.注射オーダリング・システムで，処方対象となる注射薬は？}

【A】注射オーダリング・システムで処方対象となるのは, (1)注射用麻薬, (2)造影剤, (3) 院内製剤，(4)臨時採用薬剤，(5吸入目的で使用する注射薬を除く, すべての注射薬（治験 薬を含む) です。処方期間は，期間設定により何日分でも可能です。

ただし, 治験薬と検査・処置用薬の処方については, 院内のルールがありますので守って ください。

$\square$ 注射用麻薬の処方について $\rightarrow$ Q15

口治験薬の処方について $\rightarrow$ Q16

$\square$ 検查・処置用薬の処方については $\rightarrow$ 付録 1

口臨時採用薬剮の処方については $\rightarrow$ (1)臨時採用の申請書提出（内線 35551 )

(2)手書き注射せんを用いて処方する

口吸入目的で使用する注射薬が必要なとき $\rightarrow$ Q25

Q 2. 外来の注射薬も注射オーダリング・システムで処方するのか？

【A】外来の注射薬も注射オーダリング・システムを用いて処方します。注射せんは，処 方入力後に, 外来各診療科のプリンターから印字されます。外来の場合は一部の注射薬を 配置していますので, 持参された注射せんの中で各診療科に在庫がないもの（○印を付け てください）だけを薬戍部でお渡しします。

在庫注射薬の補充は，これまで通り，週 1 回（木曜日）に行います。

なお，連日投与の場合，金曜日に土曜・日曜・月曜の処方分も個別発行で注射せんを発行 できます。

Q 3. 中央診療施設の注射薬も注射オーダリング・システムで処方するのか？

【A】手術部，放射線部，血液浄化部については，専門の用紙を用います。それ以外の部 署（集中治療部, 分婏部, 救急部, 光学医療診療部）は, 注射オーダリング・システムを 用いて処方します。

手術部と放射線部については，注射薬配置していますので, 配置注射薬の補充は, これ まで通り, 週 2 回 (月曜・木曜日) に行います（救急部と光学医療診療部は, コンピュー タによる集計が行えないので, 専門の請求用紙を用います。

Q 4 . 注射オーダリング・システムで処方した注射薬は，どのようにして病棟に供給 されるのか? 


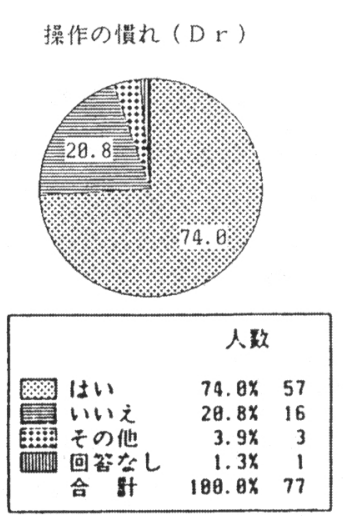

処方時、どちらが便利？
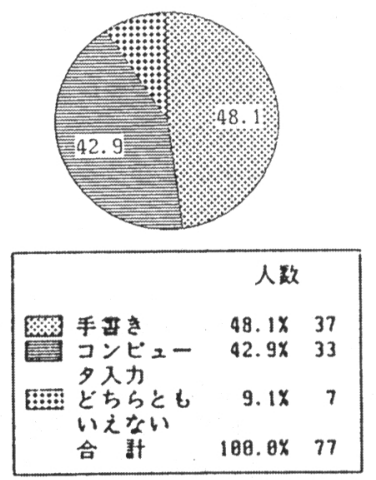

操作方法：(5)投与期間
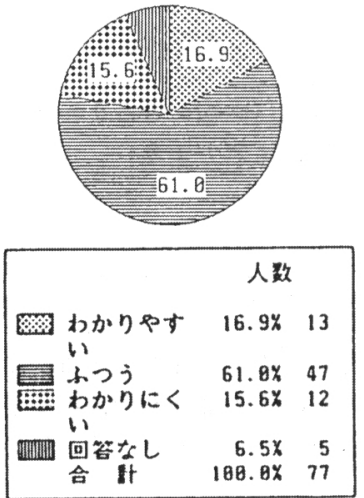

指示伝達はスムーズか？（Dr)
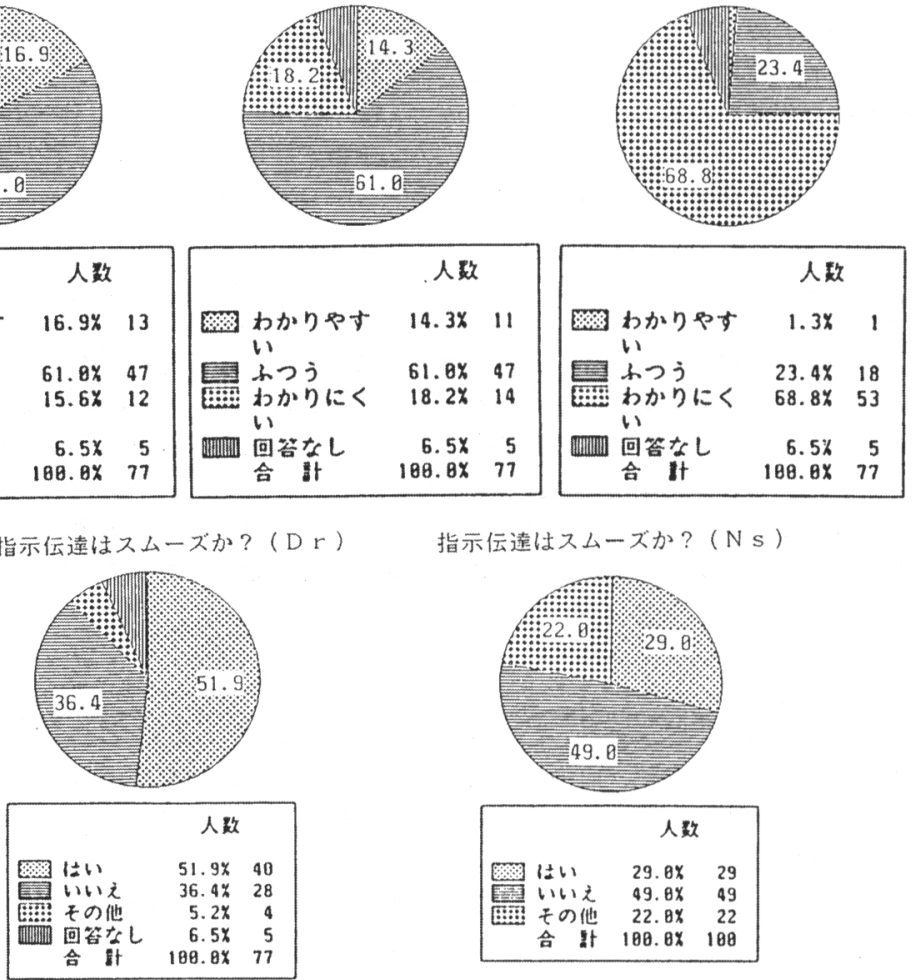

操作方法：(7)修正方法

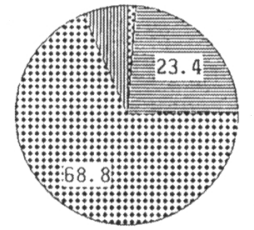

指示伝達はスムーズか？(N S )
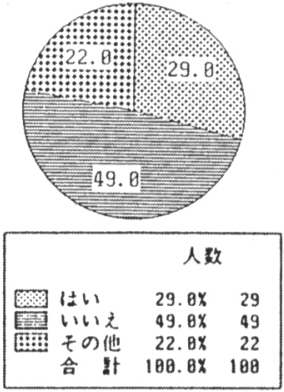

四10。医師対象アンケート調查結果：操作方法に対する質問 1995 年 10 月実施 回答率 $77 \%$ ( 77 人 $/ 100$ 人)

力」が43\%,「ケースによる」が $9 \%$ であった。

操作方法に対する印象については，(1)薬剮名入 力，(2)投与量入力，(3)注射手技入力，(4)手技コメ ント人力，(5)投与回数入力，(6)投与期間入力，(7) 修正方法の 7 項目について調査した。この結果,
(1),(2),(5),(6)については「わかりにくい」との回 答が20\%以下であったが，(3)注射手技では47\%， (4)手技コメントでは35\%，(7)修正方法では69\%と 高い回答率であった（図10）。

設問「システムの改良・機能強化希望は何 
か?」に対しては, 修正操作方法の改良, 処方デ 一夕歴の画面表示機能の追加，チェック（特に, 保険診療上の制限）機能の強化があげられた.

\section{4-2．看護婦の評価}

看護婦に対しては，指示伝達度と注射薬の供給 方法に対する評価に重点を置いた，回答率は，10 0\%（100人中 100 名）であった. 設問中システム の操作設問「医師から看護婦への指示伝達はスム 一ズか?」に対して，「はい」の回答は29\%， 「いいえ」は49\%，「その他」は22\%であり，同 じ設問に対する医師の回答は（「はい」：52\%，

「いいえ」：36\%，「その他」：12\%)とは異な る傾向を示した。また, 設問「システムの改良・ 機能強化希望は何か?」に対しては, 処方歴の画 面表示機能の追加, 混合禁忌の組み合わせに対す る処方作成段階でのチェック機能の追加があげら れた。

\section{4-3. 医事職員の評価}

医事職員に対しては，システム導入による医事 業務の変化についての評価に重点を置いた，回答 率は $87 \%$ (外来担当：13人中 13 名, 入院担当：10 人中 7 名）であった。設問「システム導入が業務 改善に役立ったか？」に対して，「はい」が外来 担当者で $100 \%$ ，入院担当者で $29 \%$ であった。 ま た, 設問「システム導入により業務量は変化した か?」に対して,「業務量が減少した」が外来担

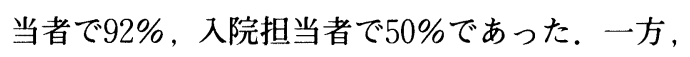
「システム導入により業務量が増加した」との回 答が入院担当者で $25 \%$ 認められた。

\section{考察}

注射オーダリングシステムを, システムと運用 面の評価, 注射薬処方時の問題点, および今後の 課題について考察する.

\section{1. システムの評価}

稼働開始 1 週間でオーダ率が，100\%に達した こと, 稼働 1 年後もオーダ率に変化がないこと, さらに, システム上の大きなトラブルも認められ ないことから, 本院での注射オーダリングシステ
ム導入は順調に行われたと評価できる。

オーダリングシステム導入による負担増が最も 大きいと考えられる医師において，約 $75 \%$ がシス テム稼働後 3 力月間でシステム操作に慣れるとい う結果が得られた。これは, 本院の内用・外用薬 処方オーダリングシステムが1992年 1 月に稼働開 始し，院内にすでに定着していることに起因して いるものと思われる.

入力操作上で問題となったのは, (1)注射手技打 よび手技コメント入力と (2)処方修正入力の 2 点で あった，注射手技については保険診療上の表現に 統一したこと, また, 手技コメントを標準的なも のに院内統一したことにより，一部の医師で従来 から使用していた表現との違いによる混乱が生じ たと思われる.コメント入力については, 稼働後 の時間経過とともに操作の慣れが観察されてい る、かなり詳細なコメントが医師により入力さ れ，注射指示の内容が看護婦に理解しやすくなっ ている(図6).

処方修正入力操作方法に対する評価は診療科間 で異なっているが, 条件（注射せん出力前か後 か? あるいは, 当日分か過去日分か未来日分 か？）による操作方法の違いが医師を混乱させて いるように思われる: 注射処方は変更が多いこと から修正操作の簡便化のためのシステム上での工 夫が必要である.

\section{2. 運用面の評価}

運用面においても，発生した問題点について院 内の会議で検討し，1点ずつ解決することによ り，大きな混乱は認められなかった。しかしなが ら, システム稼働開始 3 力月後の調査では, 次の 2 点が指摘された。第 1 点として，処方時の便利 さについて「手書き」派と「オーダリング」派が ほほ半数に分かれたこと，第 2 点として，医師か ら看護婦への注射指示の伝達度の評価において医 師（指示を出す側）と看護婦（指示を受ける側） 間で立場違いが認められたことである。これは， システム導入前 7 年間使用されてきた「注射・検 查・処置指示せん (4 枚複写)」からの急激な変化 
で，新システムに慣れないための現場の混乱に起 因するものと思われる。看護部による稼働開始 6 カ月後の調査では, 指示伝達について問題点があ げられていない。

従来の運用を大きく変えるシステムに対する評 価は，導入後の時間経過（=新しいシステムへの 慣れの程度）とともに変化すると考えられ，シス テム導入に対する評価時期の選択が重要である.

したがって，今回の調査結果の傾向が時間経過と ともに変化するのかについて，改めて調査する必 要があると思われる.

処方オーダ後の変更率が約16\%であったこと は，薬剤部が24時間を通して個人別セットを行っ ていること（=オーダ締切時間がない）によるも のと思われる。オーダ変更率が高い病棟（胸部外 科，小児科）担当の看護婦と医事職員で，注射薬 返品業務や医事会計修正業務の負担増が認められ ている。この点は，オーダリングシステム自体よ り病棟での運用に原因があり, 病棟単位でシステ 厶運用方法の改善を行う必要があると思われる. また，医事職員においては，外来部門で大幅な業 務量軽減が認められた。入院部門では, 業務内容 も複雑で担当病棟によって業務量変化に差が認め られる。システム導入後は注射せん情報が自動的 に医事システムに取り込まれるため, 減少した業 務は注射せんの入力業務である。一方，増加した 業務としては注射せん情報の修正業務があげられ る。しかしながら, 業務量としては注射せん入力 業務の方が修正業務に比べてかなり多いことか ら，全体として医事業務量は軽減したと思われ る.

システム稼働 6 月後（1995年10月）に実施され た看護部の調査結果によると，注射薬個人別セッ トへの評価に加え, 安全面と業務面で大きな改善 (1)注射せんが見やすくなり誤読がなくなった， (2)個人名ラベルの出力により準備作業が軽减され た，(3)投与量のチェック機能があり安全である， (4)返品作業が軽減された) が認められている ${ }^{91}$. 一方，薬剤師にとっては業務量はかなり増大し
たが，患者の注射処方の全体をチェックできるこ とが可能になったことにより薬片業務（注射薬供 給）の質は非常に向上したと考えられる.

\section{3. 注射薬処方における問題点}

注射薬の処方においては，内用薬・外用薬の場 合に比べて処方作成プロセスの一般化が遅れてお り, 診療科単位あるいは 施設単位の慣習的な処 方が行われている。また, 注射薬処方は, 1 回量 単位の処方であり，1 日量単位で行われる内用薬 処方時のプロセスとは異なっている。これらの注 射薬処方の特性が, 注射オーダリングシステム開 発の基本コンセプト構築時における大きな障害の ひとつとなっている. 今後, 注射薬処方のオーダ リング化が進むと予想されるが, 早急に注射薬処 方プロセスの一般的モデルを作成する必要があ る.

また，注射薬に関しては診療報酬請求上の制約 も多い，例えば，(1)分割使用が一般的な注射薬 （インスリン，ヘパリンなど），(2)小児患者の場 合の部分使用 ·分割使用の扱い, (3)検査 - 処置目 的使用時の注射手技の非加算（注：処置 - 検査目 的および前処置目的の注射薬については薬剤料の みの請求＝手技料の請求不可であり，それを診療 行為毎に行う必要がある）などが, システム化を 進める上で障害となっている。

以上の 2 点の問題解決には時間が必要である が，注射オーダリングシステム開発を通して，問 題点をさらに明確化して行くことも重要である.

\section{4 . 今後の課題}

注射オーダリングシステムは，処方オーダリン グシステムに比ベて処方内容チェック機能がそし く, 今後の進歩が強く望まれる. 今後の課題とし て，(1)注射薬混合時の変化に対するチェック機能 の開発，(2)処方オーダリングシステムとのリンク

(両システム間の相互作用, 薬剤重複チェッ ク），(3)入力された処方情報のデータベース化と 有効利用のためのツールの工夫, (4)メーカー間で の互換性のあるシステム開発があげられる。

特に, 混合時の変化に対するチェックシステム 
開発に当たっては，判断基準となる変化情報の質 がチェックシステムの有用度を決定する．メーカ 一から提供する 2 鼡間の試験データのみでは，不 十分なケースも多いと思われる。例えば，現在 UMIN（大学医療情報ネットワーク）楽郕小委員 会で試みられている注射薬情報収集システムのよ うに，実際に医療現場で遭遇した変化の事実を分 析・確認してデータベース化していく体制作りが 必要である10).

また，処方オーダリングシステムとのリンクに ついては，現在それぞれ独立している処方と注射 の両システムを統合する方向での開発が望ましい と思われる. 内用薬，外用薬および注射薬のすべ てが画面切り替え不要で処方可能となれば, 患者 個人の全処方薬剤を対象とした処方作成段階での チェック（相互作用, 薬剤重複, 投与量など）が 実現でき，患者の薬物治療の適正化推進に貢献で きることが期待される.

\section{ま と め}

本院において，注射オーダリングシステムの導 入は短期間で実現できた。この最大の要因は，医 師, 看護婦, 医事職員そして薬剤師から構成され る開発ワーキンググループのチームワークにあ る. 稼働 1 年後の現在, システム面と運用面の両 方で，トラブルは認められていない。本システム の導入により，(1)院内の注射薬供給体制（個人別 セット化の実現），注射薬管理面（適正使用と経 済性），看護業務内容の改善，および，医療事務 業務の合理化が可能となった.

\section{引用 文 献}

1) 下堂薗権洋, 児島誠治, 山王伸二, 木下力, 石 橋丸應, 熊本一朗, 酒井順哉, 医療情報学, 6 (3), 261-268 (1986).

2 ) 平野和裕, 高田勝美, 高崎, 義沖, 栗山一道, 只野壽太郎，医療情報学，10(2)，133-143 (1990).

3 ）加藤清, 山田定一, 小川信雄, 医療情報学, 12 (4), 211-214 (1992).

4 ）内田豊, 石本敬三, 神谷晃, 背戸千登世, 内藤 正幸, 第14医療情報学連合大会論文集 p. 399400 (1994).

5 ）石本敬三, 内田豊, 神谷晃, 第14医療情報学連 合大会論文集 p. 401-404（1994）。

6 ）後藤清, 遠藤秀治, 山田昌夫, 市橋寛, 大橋広 文, 高井哲, 野尻昌行, 大河内己智昭, 第14回 医療情報学連合大会論文集 p. 405-408 (1994).

7 ) 古川裕之, 島貫喜一, 古瀬裕, 前田大蔵, 竹田 和喜, 立花誉司, 中野修, 中島恵美, 市村藤 雄, 佐藤保, 分校久志, 鈴木友昭, 高田重男, 背戸清二, 水上康光, 病院薬学, 20(4), 328-337 (1994).

8）古川裕之, 毎田千恵子, 大森美加子, 清水みさ を, 桶展代, 旭満里子, 中島恵美, 市村藤雄, 佐藤保, 分校久志, 和田出静子, 野川文子, 氷 見嘉康，宮崎逸夫，病院薬学投稿中.

9 ）干場順子, 野川文子, 平田万里子, 小川洋子, 前多公子, 山内由美子, 浦美奈子, 和田出静 子, 佐藤保, 分校久志, 古川裕之, 平成 7 年度 国立大学附属病院医療情報システムシンポジウ ム演題論文集，p. 261-264（1996）.

10）西村久雄, 川端菜緒美, 平野栄作, 岩本喜久 生, 古川裕之, 市村藤雄, 東海林徹, 仲川義 人, 折井孝男, 伊賀立二, 平成 7 年度国立大学 附属病院医療情報システムシンポジウム演題論 文集 p. 129-131（1996）. 